\title{
sciendo
}

\section{TEMPORAL TRENDS IN PERFORMANCE AND HATCHABILITY TRAITS OF EIGHT STRAINS OF HENS COVERED BY THE GENE POOL PROTECTION PROGRAMME IN POLAND*}

\author{
Joanna Obrzut*, Jolanta Calik, Józefa Krawczyk \\ Department of Poultry Breeding, National Research Institute of Animal Production, \\ 32-083 Balice n. Kraków, Poland \\ •Corresponding author: joanna.obrzut@iz.edu.pl
}

\begin{abstract}
The aim of the study was to determine trends in performance and hatchability traits of eight strains of hens that have been covered by the gene pool protection programme in Poland over ten years/generations. The study involved conservation populations of laying hens: Greenleg Partridge (Z-11), Yellowleg Partridge (்̇-33), Sussex (S-66), Leghorn (H-22, G99), Rhode Island Red (R-11, K-22) and Rhode Island White (A-33), which were maintained at the Experimental Station of the National Research Institute of Animal Production in Chorzelów. The following productive traits were analysed for each population: body weight at $20 \mathrm{wk}(\mathrm{g})$, egg weight at 33 and 53 wk, sexual maturity and number of eggs laid per hen up to $56 \mathrm{wk}$ of age. Mortality and culling were also recorded during rearing and production periods. Furthermore, effective population size $\left(\mathbf{N}_{\mathrm{e}}\right)$ and inbreeding coefficient in the population $\left(F_{\mathrm{x}}\right)$ were calculated for each strain. The analysis of the performance results of the eight strains of hens and their trends indicate that the methods of conservation breeding adopted for these populations enable effective implementation of the conservation programme. The strains were found to differ in all the performance traits subjected to evaluation. Over the $\mathbf{1 0}$ generations, the strains examined showed high survival and hatchability parameters during both rearing and production periods. The currently used random mating system proved effective to prevent the populations from an increase of inbreeding. However, a worrying downward trend in body weight was observed in some strains.
\end{abstract}

Key words: laying hens, biodiversity, health, productivity

Protection of local poultry breeds plays a significant role both in highly developed countries, where it follows the recommendations of sustainable agricultural policy, and in less developed countries, where native poultry farming predominates. The scientific literature provides an increasing number of studies with local poultry breeds

*Funded by multi-annual program number 503-181-909. 
all over the world, exploring the genetic structure, evaluating different methods to improve the productivity of these populations, and showing the results of crossing with other breeds (Boichard et al., 1997; Caballero and Toro, 2000; Woelders et al., 2006; Van Marle-Köster et al., 2008; Marquez et al., 2010; Mtileni et al., 2012; Pham et al., 2016; Vostrý et al., 2020). The findings of Cervantes et al. (2011) demonstrate that small populations of the native breeds of animals maintained without foreign blood should be genetically tested to monitor the effective population size and the degree of inbreeding. When kept at a proper level, these parameters ensure that the conservation flocks are in good condition. Such studies allow for evaluating the effectiveness of the adopted conservation programme, while their results are used to develop long-term strategies for native breed protection.

The genetic parameters and the productivity of the Polish hen populations included in the gene pool protection programme were analysed during the period of Poland's economic transition (1990s) by Cywa-Benko (2002). The introduction of a free market and liberal market economy led to the failure of state-owned farms, which also held native breeds of hens. These small populations of hens were characterised by high mortality and poor health condition, which put some of the breeds at risk of extinction. It was then that the National Research Institute of Animal Production decided to move the native hen breeds to the Institute's Experimental Station in Chorzelów, which today holds 8 strains. Most of these populations were included by FAO in the list of the world genetic resources that need to be conserved (World Watch List, FAO, 2000). Greenleg Partridges are the oldest Polish breed known since the 18th century. They have characteristic partridge-like plumage and green legs. Hens of this breed are very well adapted to extensive free-range management, resistant to disease, and lay eggs with a high yolk percentage, which has a positive effect on their taste. Cocks are raised on grass paddocks and have low weight gains, but their meat is tasty, low in fat, and dark in colour like in wildfowl. In the 1960s, in an effort to improve the production traits, Greenleg hens were crossed with New Hampshire cocks; the intensive selection over the next few generations resulted in a new breed known as Greenleg Partridge ( $\dot{Z}-33)$. This breed was characterised by partridge-like plumage, higher body weight and laying performance, and yellow colour of the legs, carcasses and skin. Popular as a dual-purpose type, Rhode Island Red hens formed around $50 \%$ of the population in commercial farms and backyard flocks until the mid-1970s. Hens of this breed are recommended for backyard keeping, and due to their genetically determined resistance to Marek's disease they show good health under free-range farming conditions. After the first year of egg production, they are fit to be used as stewing hens. Sussex (S-66) hens, which were imported to Poland after the Second World War as part of UNRRA supplies, have white skin and higher body weight, and when crossed with the Rhode Island Red and New Hampshire breeds they produce autosexing hybrids. Due to the striking white plumage they are highly valued by fancy breeders and owners of small farms. The markedly lighter Leghorn hens were imported to Poland in 1967 from the British firm Sykes (strain G-99) and the Canadian firm Kathman (H-22) and selected for high egg production and heavy white-shelled eggs. These hens were designed for intensive, large commercial production. Genetic selection of Rhode Island Red (K-22) and Rhode 
Island White (A-33) in Poland began in the late 1970s at the Pedigree Hen Farm in Duszniki. In 2009 these populations were moved to the Chorzelów Experimental Station of the National Research Institute of Animal Production. K-22 and A-33 hens are characterised by a different genetic structure and genetic origin compared to the other strains kept in Poland, and when crossed with other strains they show a high level of heterosis. Each of these breeds/strains, covered by the gene pool protection programme, forms a distinct genotype, which determines the presence of unique traits that are not found in the breeds selected for high productivity (Cywa-Benko, 2002; Calik, 2008; Krawczyk and Calik, 2010). The findings of Polak et al. (2021), which account for the latest criteria of evaluating the risk status of the breeds show "at risk" status for all the 8 strains of hens studied in the present paper.

Wężyk et al. (2000) pointed to variable DNA polymorphism in the populations of Z-11, Z-33, R-11, S-66, G-99 and H-22 hens. The authors showed that the breeds R-11 and S-66 were genetically closest to each other. The study also observed small genetic distance in Z-11 and Ż-33 hens, which share common ancestry, and these findings were confirmed by Brodacki et al. (2001) based on the study of blood serum protein polymorphism. Contrary to expectations, the analysed strains of G-99 and $\mathrm{H}-22$ hens were genetically not very similar, while genetically the most distinct from the other strains under study were H-22 hens, which were selected the longest for egg laying out of all the analysed breeds, as reflected in the DNA profile. These data differ from the findings of Brodacki et al. (2003), who observed the smallest genetic distance between strains G-99 and H-22, as well as high similarity among the three strains derived from Greenleg Partridge hens (Z-11, ZKF and Ż-33).

Semik and Krawczyk (2011), who analysed the state of the world's genetic resources for hens, stressed the high value of the Polish populations, which make a valuable contribution to the gene pool in Europe. The authors underlined that molecular characteristics may play a major role in estimating the variation, in describing and evaluating population structure while being an effective tool for counteracting the increase of inbreeding. Among the most important indicators of the threat of a breed becoming extinct, Alderson (2010) mentioned the number of females in the active population and the effective population size. In Poland, periodic studies on using the potential of native poultry breeds have confirmed these birds show genetic variation, high fertility and hatchability, as well as the effect of housing conditions on production traits (Cywa-Benko, 2002; Calik, 2008; Krawczyk and Calik, 2010; Krawczyk et al., 2012; Krawczyk, 2018; Dobrzański et al., 2019). The 10-year analysis (2009-2018) of the production parameters of 8 layer strains included in the conservation programme fits into the international studies in this area and may provide a source of information for scientists engaged in animal biodiversity.

The aim of the study was to determine trends in performance and hatchability traits of eight hen strains that have been covered by the gene pool protection programme in Poland over ten years/generations. 


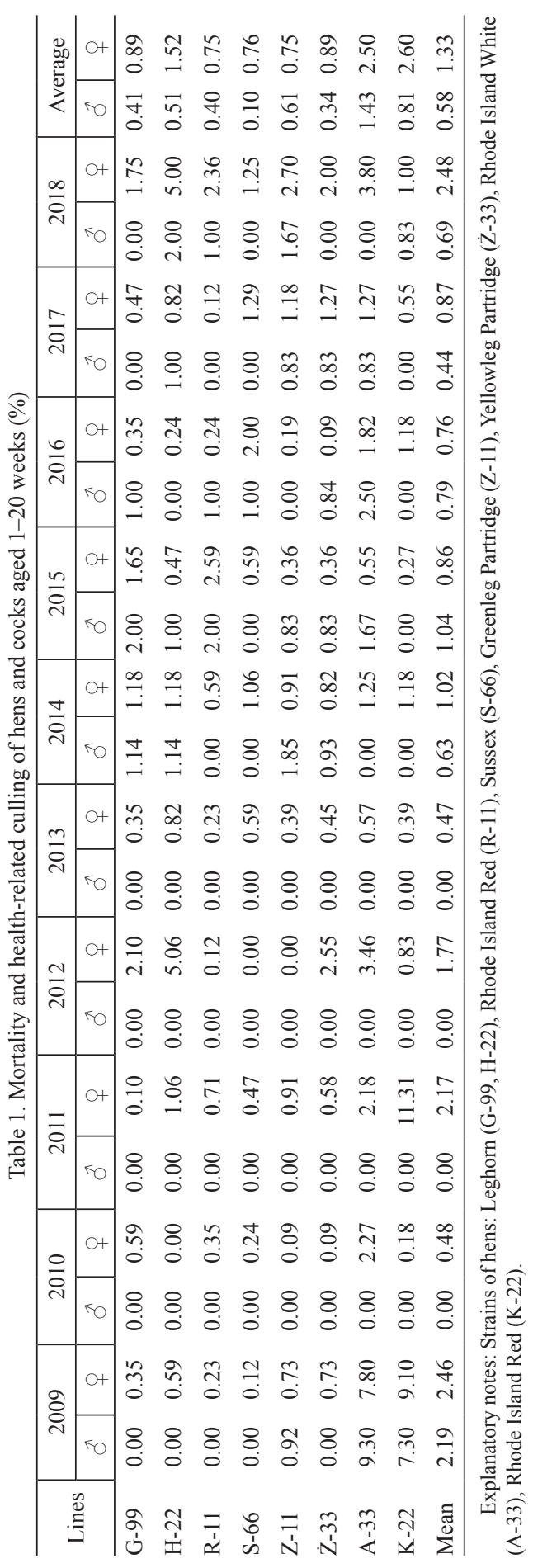




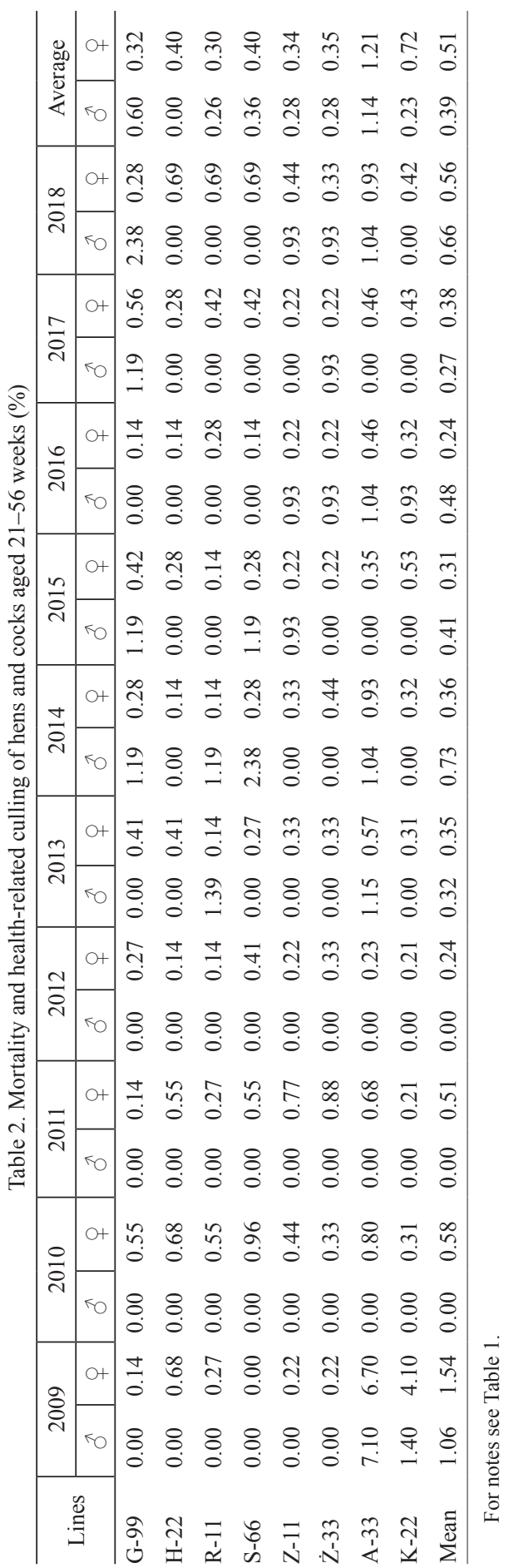




\section{Material and methods}

The study material consisted of the conservation populations of laying hens: Greenleg Partridge (Z-11), Yellowleg Partridge (Ż-33), Sussex (S-66), Leghorn (H-22, G99), Rhode Island Red (R-11, K-22) and Rhode Island White (A-33), which were maintained at the Experimental Station of the National Research Institute of Animal Production in Chorzelów. All the strains were kept at a ratio of 1 male to 8-10 females. The number of birds per strain and year is presented in Table 1 .

Hens and cocks were kept under optimum environmental conditions at $16-20^{\circ} \mathrm{C}$ and relative humidity of $60-80 \%$. The barn system with $40-50$ birds per compartment and stocking density of 5 birds $/ \mathrm{m}^{2}$ was used. Throughout rearing and production periods, birds were fed complete standard diets ad libitum.

The following parameters, obtained during the years 2009-2018, were analysed based on the farm records (database) and measurements made:

- mortality and health-related culling (birds were selected based on their conformity to the breed standard) during rearing and production periods,

- body weight of the birds at 20 weeks of age,

- sexual maturity in the flock (days of age from hatching to attainment of $50 \%$ egg production),

- average egg weight at 33 and 53 weeks of age (all eggs laid during the study week were evaluated),

- number of eggs laid up to 56 weeks of age.

Hatchability results were determined based on percentage of hatched chicks from set and fertile eggs. Egg fertilisation was also evaluated. Chicks were hatched in a Petersime incubator (Belgium), in accordance with the recommendations for temperature and relative humidity.

Effective population size $\left(\mathrm{N}_{\mathrm{e}}\right)$, which depends on the number of females and males per flock and reflects the rate of loss of genes due to random genetic drift, was calculated based on Wright's formula (1931). The increase in flock homozygosity $\left(\mathrm{F}_{\mathrm{x}}\right)$, which is inversely proportional to the effective population size, was calculated.

Based on linear regression equations using the coefficient $\left(\mathrm{R}^{2}\right)$, significance of the trend line $(\mathrm{p})$ and standard error of estimation $\left(\mathrm{S}_{\mathrm{e}}\right)$ for production traits and hatchability parameters, the temporal trends were determined.

The data were visualized in figures (program Excel), while the statistical parameters for the regression model to determine the trend line were estimated using Statistica 13 package.

\section{Results}

As is evident from Figures $1 \mathrm{a}-\mathrm{b}$, the mean number of birds ranged from 78 to 106 for males and from 725 to 950 for females; the highest number of birds in different years and in the entire evaluation period was noted in strains Z-11, $\dot{Z}-33$, A-33 and K-22. The mean effective size of the populations $\left(\mathrm{N}_{\mathrm{e}}\right)$, which depends on the number of males and females, ranged from 281.55 in strains H-22, R-11 and 
S-66 to 382.24 in strain K-22; this had a direct effect on the low level of inbreeding $\left(\mathrm{F}_{\mathrm{x}}\right)$, which averaged from $0.13(\mathrm{~K}-22)$ to 0.18 (G-99, H-22, R-11 and S-66) (Figures $2 \mathrm{a}-\mathrm{b}$ ). Since 2014 there has been an increase in the number of cocks in the analysed populations, which caused a considerable increase in $\mathrm{N}_{\mathrm{e}}$ and a reduction in $\mathrm{F}_{\mathrm{x}}$.

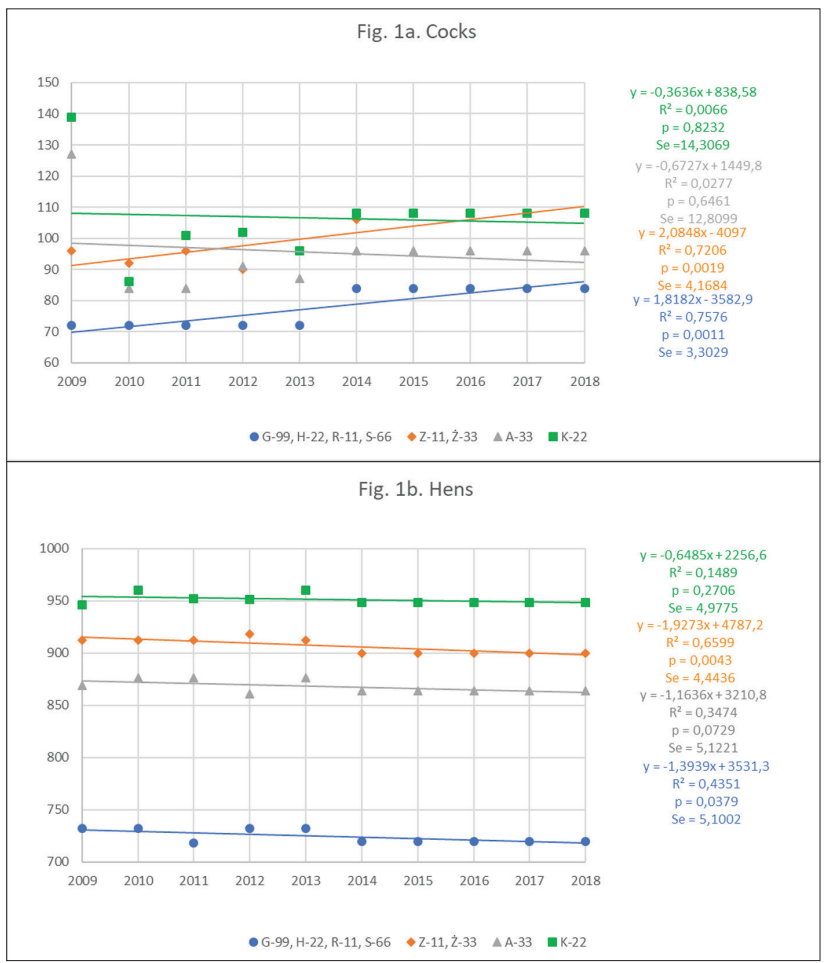

Explanatory notes: Strains of hens: Leghorn(G-99, H-22), Rhode Island Red(R-11), Sussex (S-66), Greenleg Partridge (Z-11), Yellowleg Partridge (Ż-33), Rhode Island White (A-33), Rhode Island Red (K-22); $\mathrm{R}^{2}$ - coefficient of model fitting; $\mathrm{p}$ - significance of trend line; $\mathrm{S}_{\mathrm{e}}$ - standard error of estimation.

Figure $1 \mathrm{a}-\mathrm{b}$. Trends in number of cocks and hens included in the genetic resources conservation programme in 2009-2018

During the rearing period (2009-2018) mean mortality and health-related culling in the analysed populations were low and did not exceed $1.43 \%$ in males and $2.60 \%$ in females (Table 1$)$. Higher bird mortality $(>9.00 \%$ ) was only noted in 2009 (males A-33 and females K-22) and in 2011 (>11.00\%; females K-22). As is evident from Table 2, mean health status of the cocks and hens during the production period (2009-2018) was also favourable. Similar to the rearing period, higher mortality was observed in strains A-33 (males and females) and K-22 (females) in 2009. 
Trends in body weight of different strains and years are shown in Figures $3 \mathrm{a}-\mathrm{h}$. In the years 2009-2018, mean body weight was highest in birds of strain R-11 and lowest in strains G-99, H-22 and Z-11. During the analysed time interval, male body weight showed a downward trend (8.55-32.70 g/year) in strains G-99, H-22, S-66 and A-33, and an upward trend (11.70-27.52 g/year) in strains Z-11, Ż-33 and K-22. Significance $(\mathrm{P} \leq 0.05)$ of the trend line was statistically confirmed only for strains Ż-33 and A-33. The lowest coefficient of estimation was determined in strain H-22 $\left(\mathrm{S}_{\mathrm{e}}=54,4392\right)$.

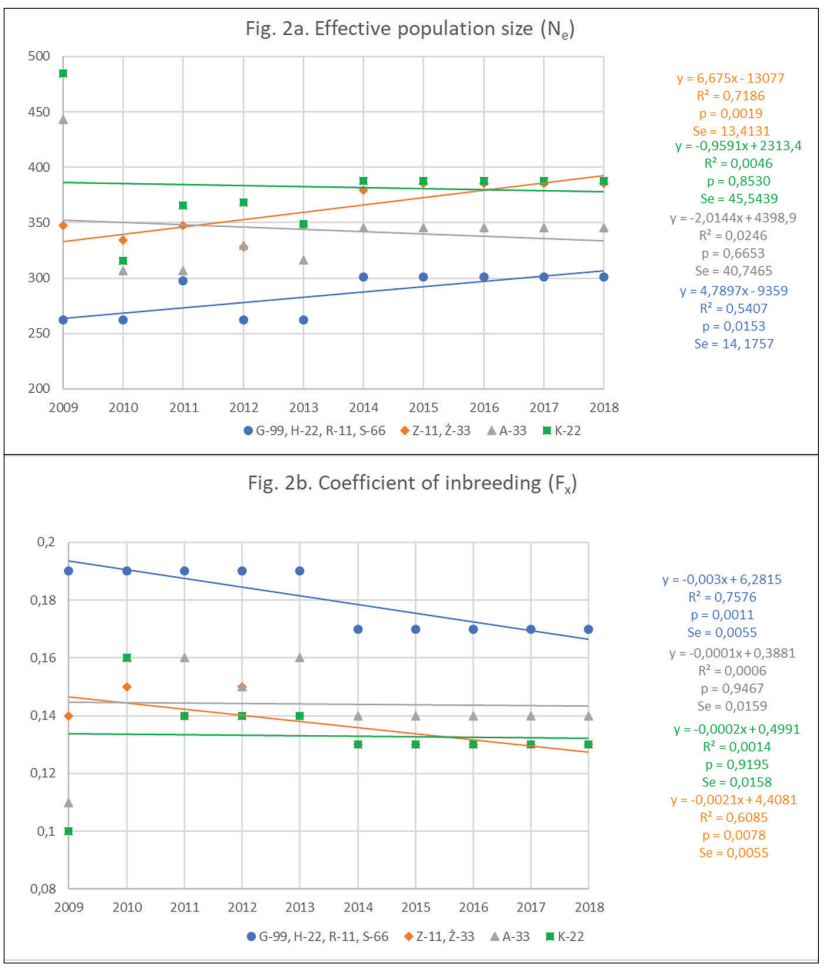

For notes see Figure $1 \mathrm{a}-\mathrm{b}$.

Figure $2 \mathrm{a}-\mathrm{b}$. Trends of effective population size $\left(\mathrm{N}_{\mathrm{e}}\right)$ and coefficient of inbreeding $\left(\mathrm{F}_{\mathrm{x}}\right)$ in flocks included in the genetic resources conservation programme in 2009-2018

In the hen populations, a negative trend in body weight was observed in strains G-99, H-22, R-11, S-66 and Z-11 (8.23-22.92 g/year), a stable trend in strain Ż-33, and a positive one in strains A-33 and K-22 (8.30-14.00 g/year). Only in strain K-22 was a significant trend line observed, with a low coefficient of estimation $\left(\mathrm{S}_{\mathrm{e}}=53.0165\right)$. 


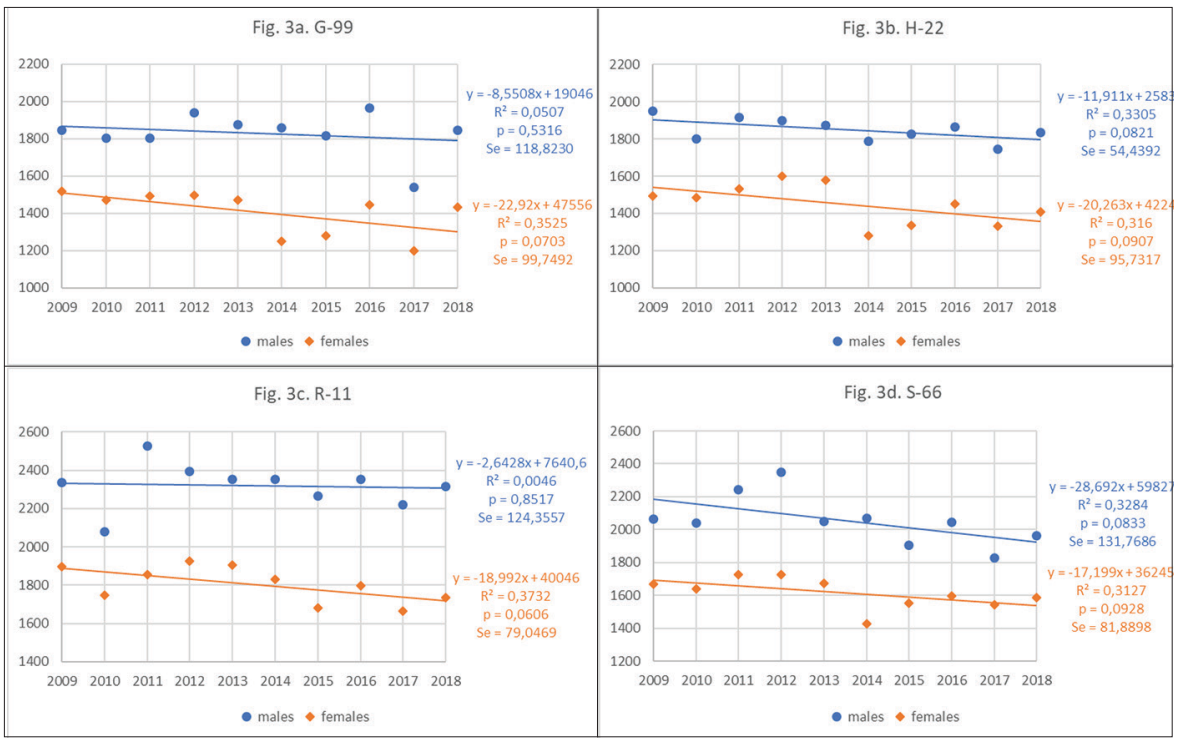

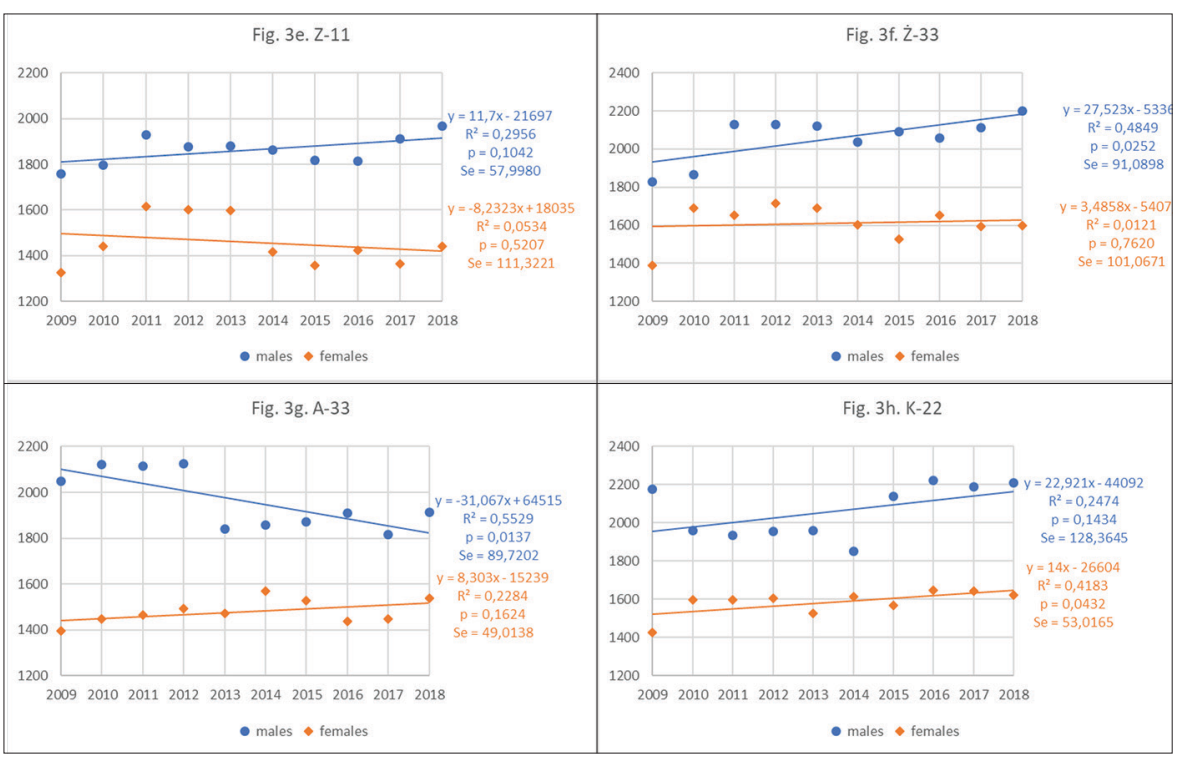

For notes see Figure $1 \mathrm{a}-\mathrm{b}$.

Figure $3 \mathrm{a}-\mathrm{h}$. Trends in body weight in the strains of the hens covered by the gene pool protection programme in 2009-2018 


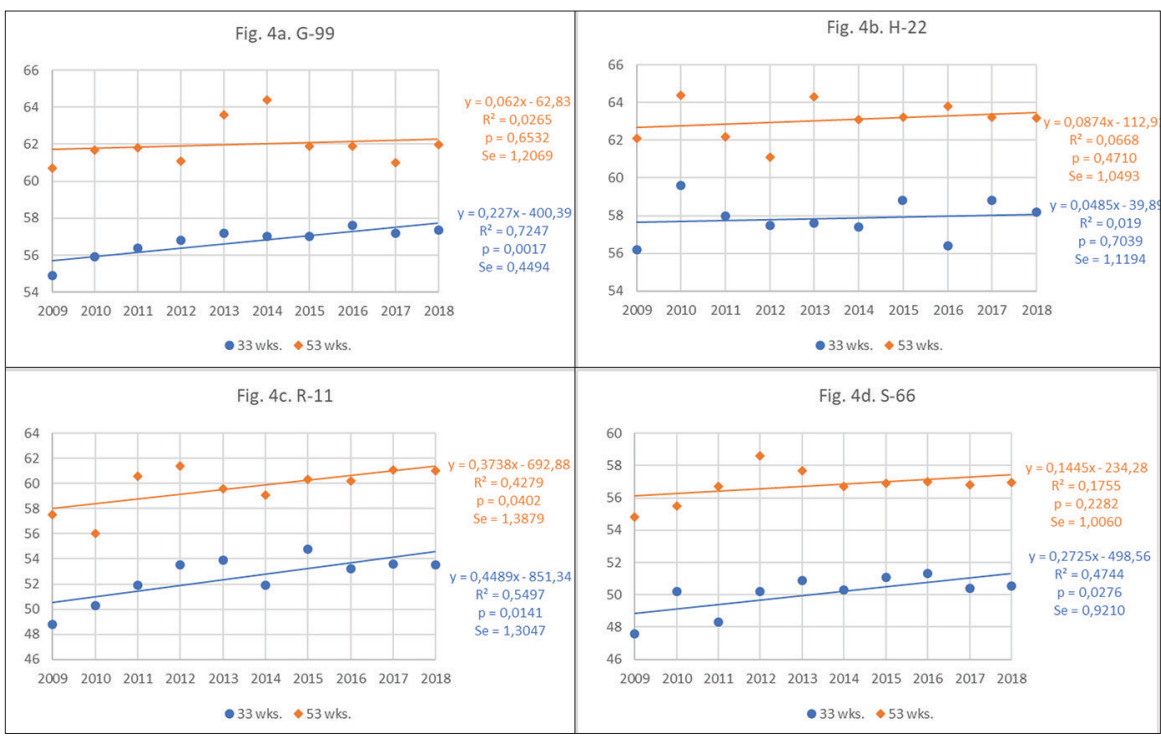

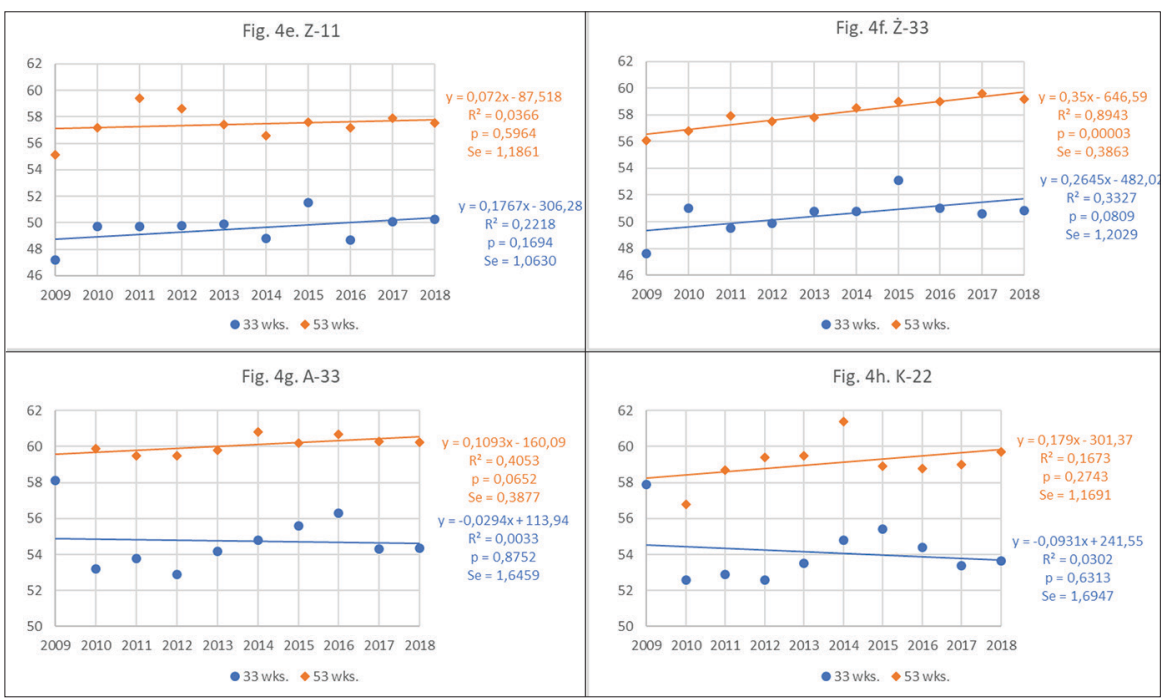

For notes see Figure $1 \mathrm{a}-\mathrm{b}$.

Figure $4 \mathrm{a}-\mathrm{h}$. Trends in egg weight in the strains of the hens covered by the gene pool protection programme in 2009-2018 


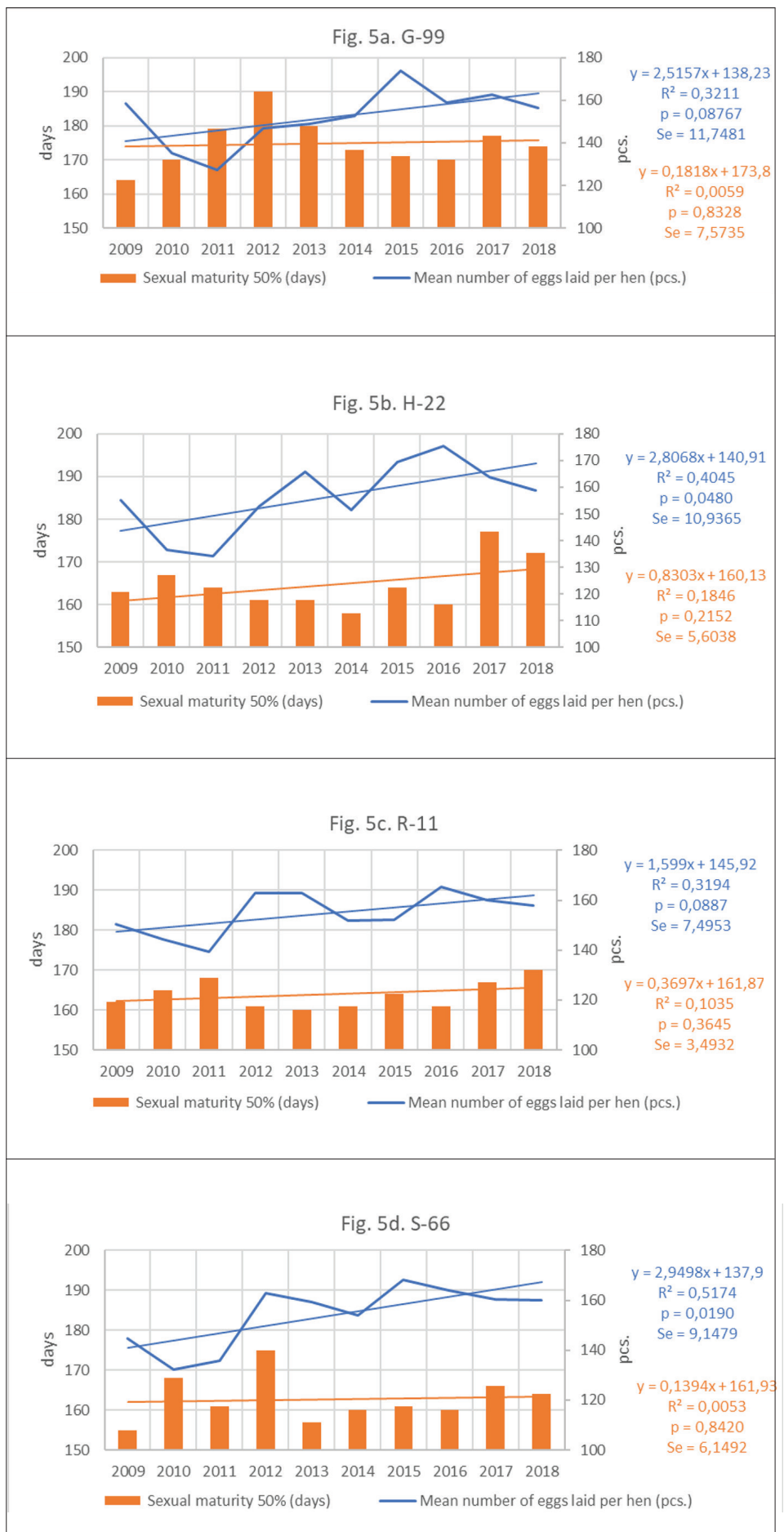




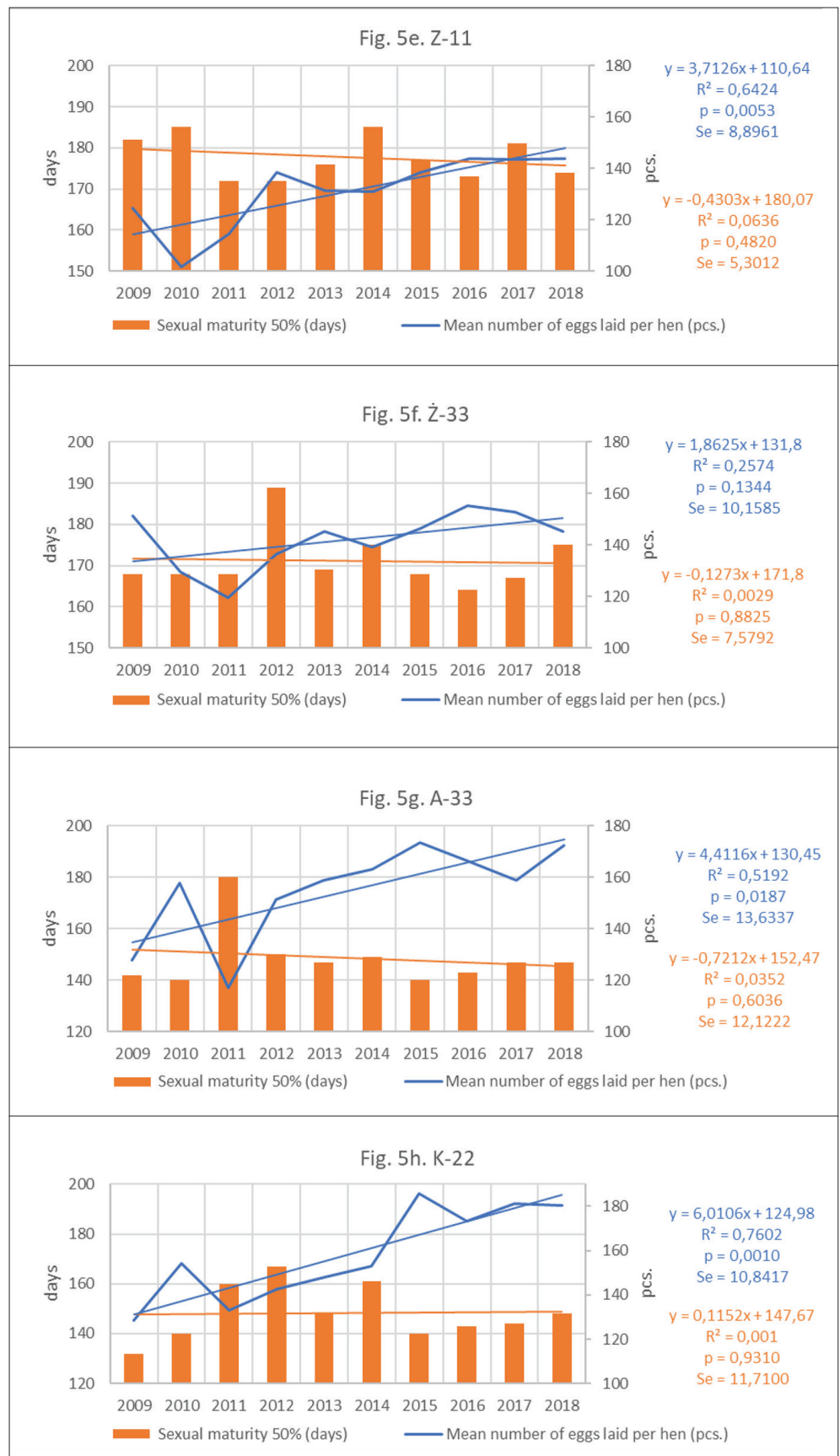

For notes see Figure $1 \mathrm{a}-\mathrm{b}$.

Figure $5 \mathrm{a}-\mathrm{h}$. Trends in sexual maturity and number of eggs in the strains of the hens covered by the gene pool protection programme in 2009-2018 


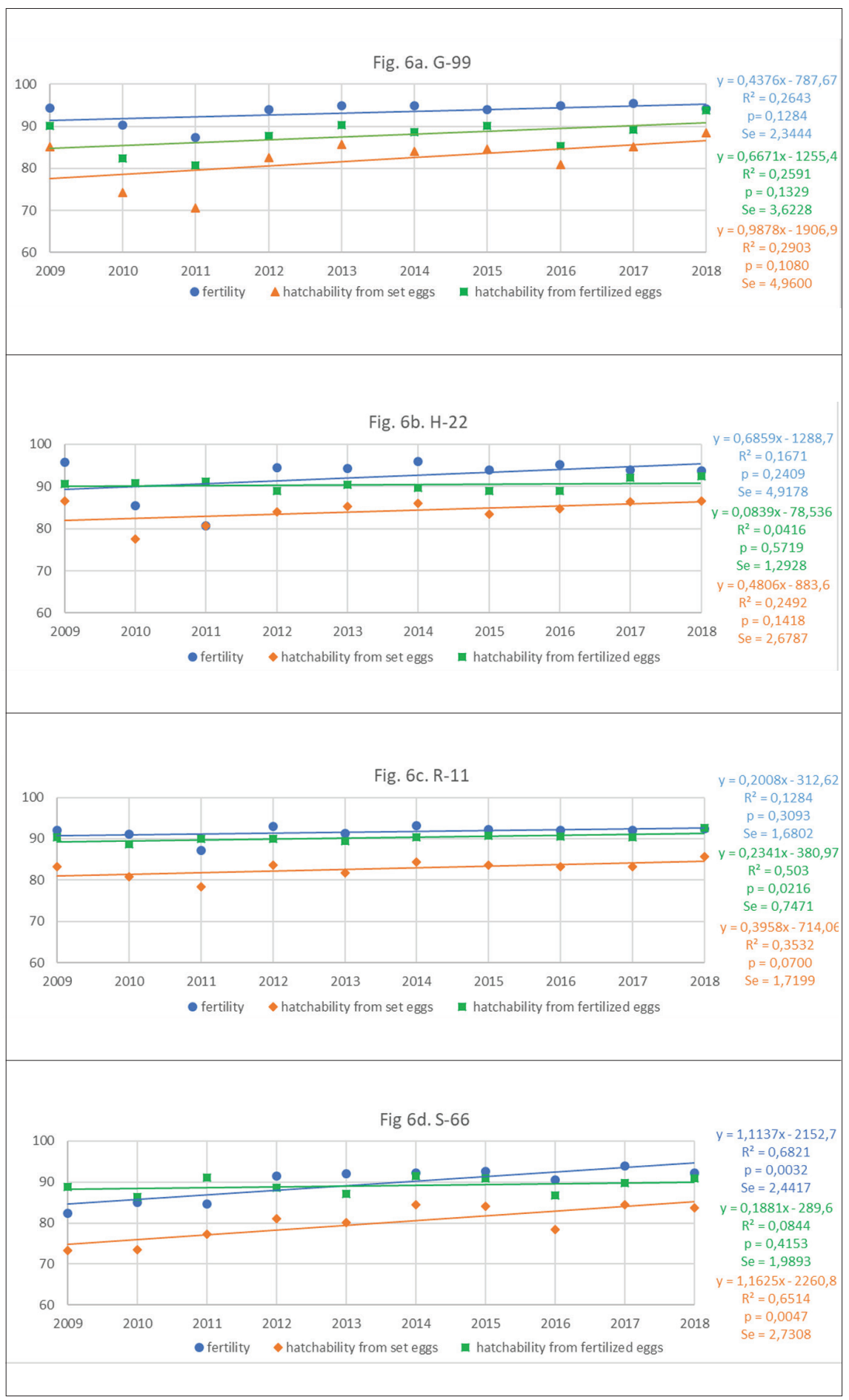




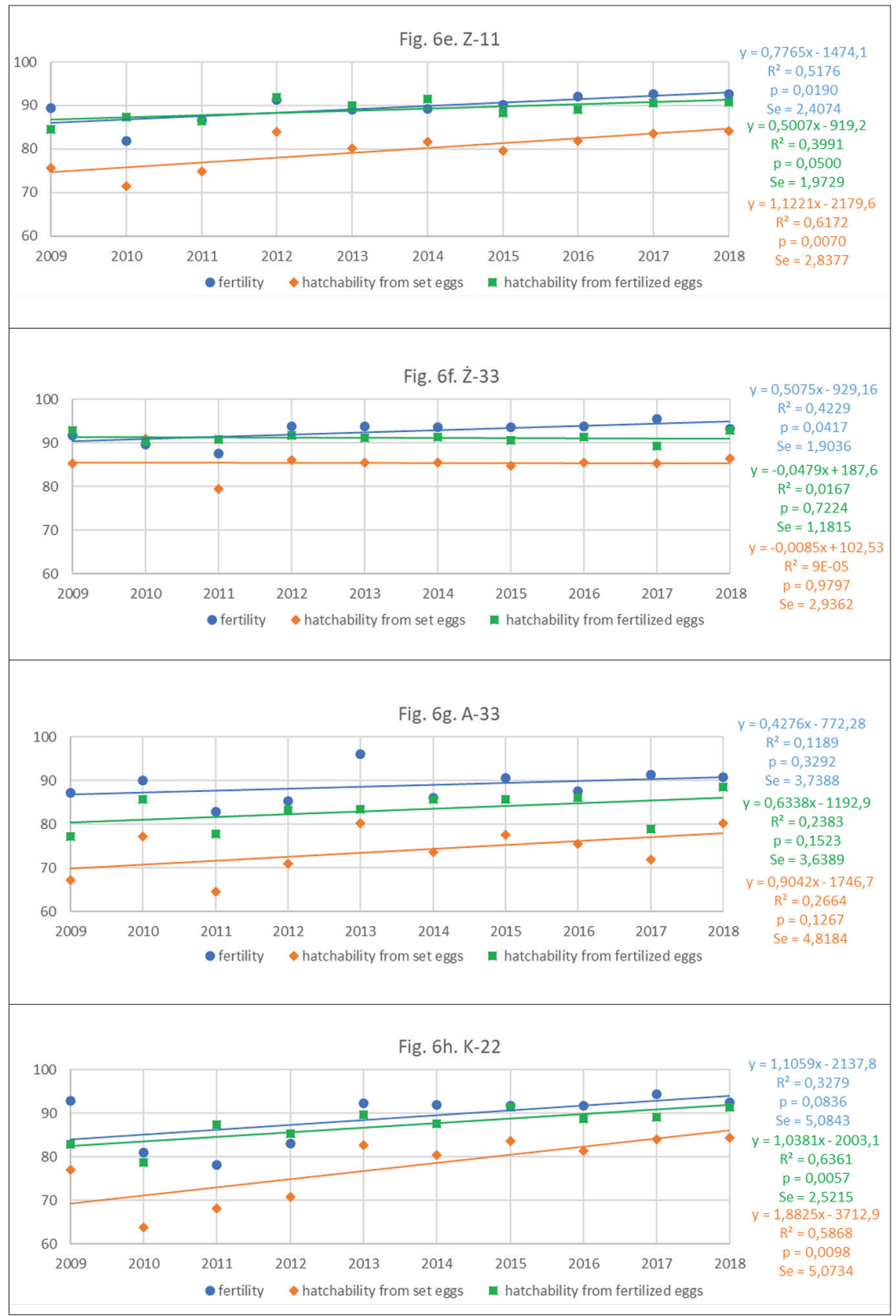

For notes see Figure $1 \mathrm{a}-\mathrm{b}$.

Figure $6 \mathrm{a}-\mathrm{h}$. Trends in hatchability parameters in the strains of the hens covered by the gene pool protection programme in 2009-2018 
In the years 2009-2018 among the analysed strains, mean egg weight at 33 and 53 weeks of age (Figure $4 \mathrm{a}-\mathrm{h}$ ) was highest in G-99 and H-22 hens (57.30 $\mathrm{g}$ and $62.53 \mathrm{~g}$ ), intermediate in R-11, K-22 and A-33 hens (53.81 g and $59.64 \mathrm{~g})$, and lowest in Z-11, Z-33 and S-66 birds (50.05 g and $57.45 \mathrm{~g})$. The difference in this trait between 33 and 53 weeks of age ranged from $5.23 \mathrm{~g}$ to $7.40 \mathrm{~g}$. Regardless of strain egg weight during the discussed period showed a positive temporal trend, and the trend line was significant $(\mathrm{P} \leq 0.05)$ at 33 and 53 weeks for strains $\mathrm{R}-11, \mathrm{~S}-66$ and G-99 and for strains R-11 and $\dot{Z}-33$, respectively. One exception were the measurements of egg weight in 33-week-old hens of strains A-33 and K-22, which showed a slight negative trend (0.03-0.1 g/year), without marked statistical differences in the trend line.

Figures $5 \mathrm{a}-\mathrm{h}$ present the data for sexual maturity and number of eggs laid by the hen strains under study. These two traits show considerable variation between years. In the years 2009-2018 A-33 and K-22 hens were the earliest to reach sexual maturity (day 149 on average) and Z-11 hens the latest (day 178 on average). Over the years, the entry into egg production showed a negative trend in strains Z-11, Ż-33 and A-33 (0.13-0.72 day/year), a stable trend in strains S-66, K-22 and G-99 ( 0.14 day/year) and a slight positive trend in strains H-22 and R-11 (0.37-0.83 day/ year), but the trend lines for this trait were not significant. These fluctuations had a marked effect on the number of laid eggs evaluated until day 56 of age. The mean egg production was highest in strain K-22 (161.30 eggs/hen) and lowest in strain Z-11 (131.06 eggs/hen). In all the analysed strains, worth noting is the reduction (by around $13 \%$ ) of egg production in the years 2010-2011. However, this had no direct effect on the temporal trends for this trait, which were positive (1.60-6.01 eggs/year) over the period of 10 years, while the trend line was significant $(\mathrm{P} \leq 0.05)$ for strains H-22, S-66, Z-11, A-33 and K-22.

As is evident from Figures $6 \mathrm{a}-\mathrm{h}$, there were positive trends for hatchability parameters in all the tested strains during the studied period (2009-2018). Significance $(\mathrm{P} \leq 0.05)$ of the trend line was confirmed for egg fertilisation in strains S-66, Z-11 and $\dot{Z}-33$, and for hatchability from set and fertile eggs in strains S-66, Z-11, K-22 and R-11, Z-11, K-22, respectively. In the evaluated strains the coefficient of estimation $\left(\mathrm{S}_{\mathrm{e}}\right)$ for the parameters reported above ranged from 1.18 to 5.08. Over the years analysed the G-99, H-22, R-11 and Ż-33 populations demonstrated high egg fertility (92.49\% on average), hatchability from set eggs ( $83.61 \%$ on average) and hatchability from fertile eggs (89.93\% on average). In the other strains (S-66, Z-1, A-33 and $\mathrm{K}-22$ ), these parameters were lower, by 3.26 percentage points (pp) for egg fertility, and by 5.80 and $2.78 \mathrm{pp}$ for hatchability from set and fertile eggs, respectively.

\section{Discussion}

Because no selection is practiced in conservation flocks, all the changes in the values of the studied parameters are mainly due to genetic characteristics of a breed and the environmental conditions. An important part of breeding work in these flocks is the random selection of pairs for mating, based on cock rotation among subgroups of hens (Krawczyk and Calik, 2010). This is of particular importance because the 
primary purpose of the conservation programme is to preserve different breeds/ strains of laying hens from extinction by keeping genetic equilibrium in each protected strain unchanged and by preserving breed-specific characteristics. It should be noted that in Poland the conservation programme includes not only old native breeds of poultry, but also the populations imported fifty years ago, which are very well adapted to local environmental conditions and production systems; therefore, they are important for Polish breeders and may serve as a valuable pool of genes which can be used to produce hybrids in the future (Calik et al., 2012).

Analysis of the estimates for effective population size $\left(\mathrm{N}_{\mathrm{e}}\right)$ and inbreeding coefficient $\left(\mathrm{F}_{\mathrm{x}}\right)$ indicates that sex ratio in the flocks $(1 \quad \hat{\delta}: 8-10$ o $)$ and the rotational mating system used in the four bird groups are effective in protecting the analysed hen populations from inbreeding increase, which is consistent with the earlier observations of Cywa-Benko (2002), Calik (2008) and Krawczyk and Calik (2010), who reported comparable values of $\mathrm{N}_{\mathrm{e}}$ and $\mathrm{F}_{\mathrm{x}}$. Vostrý et al. (2020) investigated the Czech population of Czech Gold Speckled hens and estimated the inbreeding coefficient in this population to be low $\left(F_{x}=0.021\right)$. Spalona et al. (2007), who studied 41 local breeds of hens raised in Europe, noted much higher variation in the inbreeding coefficient $\left(\mathrm{F}_{\mathrm{x}}\right)$ than in our study, but for half of the analysed population this parameter ranged from 0.20 to $0.71 \%$. Also higher flock inbreeding coefficients $(0.7-1.9 \%)$ were reported by Pham et al. (2016), who analysed pedigree and molecular data for 8 Taiwanese breeds of hens. In the study by Abdelqader et al. (2007) with hen populations maintained in Jordania, flock inbreeding coefficient was very high at $5.5 \%$. As underlined by Szwaczkowski (2003) and Vostrý et al. (2020), inbreeding is considered a constraint on production due to its negative effect on health and productivity of the hens.

Survival of the analysed breeds was high during rearing and production periods alike. Compared to the earlier studies of Calik (2008) and Krawczyk and Calik (2010), strains A-33 and K-22 showed improved health as a result of better environmental conditions and professional care after these flocks were moved from a liquidated farm into the Chorzelów farm, which is highly experienced in conservation breeding. As indicated by Cywa-Benko (2002), a similar situation already occurred in the 1990s for the other strains of hens, which were transferred from a liquidated farm in Życzyn (Podzamcze Horticultural Farm) to the Chorzelów farm. Provision of the birds with optimum environmental and feeding conditions, and veterinary prevention, in particular the vaccination programme, have considerably improved their health, which the studies over the last 20 years showed to be very good (CywaBenko, 2002; Calik, 2008; Krawczyk and Calik, 2010).

Growth of birds is a combination of traits determined by genetic and environmental conditions, which are dependent on the age of birds (Singh et al., 2000). As reported by Calik (2009) and Padhi (2016), reared hens should grow rapidly to reach optimum body weight for their type at sexual maturity. Therefore, before attaining sexual maturity, pullets coming early into egg production should be subjected to a short, non-productive rearing period as well as rapid and rhythmic regulation of egg weight. In the gene pool protection programme for laying hens, body weight is the main characteristic of the breed standard and its stability over the period of sev- 
eral years confirms that the birds were well chosen for flock rotation. Cywa-Benko (2002), despite the high coefficient of heritability estimated for body weight $\left(\mathrm{h}^{2}>0.5\right.$ $0.6)$ over 9 generations, observed no positive temporal trends for this trait in young hens ( 20 weeks old) and older hens ( 33 weeks old). According to the author, this may be due to the fact that these strains are highly conserved breeds. Another study of five generations (2004-2008) demonstrated that the body weight of 20-week-old G-99, S-66, R-11, Z-11 and Ż-33 hens remained stable and showed a small upward trend, while in the other strains (H-22, A-33 and K-22) this trait varied widely. Our study showed that over the course of recent years, G-99, H-22, S-66 strains and A-33 cocks exhibited a downward trend in body weight. These results suggest that breeders should place greater emphasis on this trait in the next generations of the birds.

The literature indicates that egg weight is generally positively correlated to body weight of birds, and the coefficient of heritability $\left(\mathrm{h}^{2}\right)$ is around 0.50 (Hazary et al., 2000; Calik, 2002; Szwaczkowski, 2003; Krawczyk, 2006). The consistent improvements in the mean egg weight between 1991 and 2000 for all the analysed strains, except S-66, were reported by Cywa-Benko (2002). Unfortunately, the next analysis (2004-2008) showed worryingly declining temporal trends in egg weight for all the studied hen strains except K-22 and A-33 (Krawczyk and Calik, 2010). It is worth noting that our study showed a considerable improvement of this trait, and no negative trends in egg weight with decreasing body weight were observed. The high variation in the body weight of cocks $(1.3-4.5 \mathrm{~kg})$ and hens $(1.0-3.3 \mathrm{~kg})$ and in egg weight (40-60 g) was reported by Özdemir et al. (2013) for 6 local breeds of hens raised in Italy and Turkey. According to Fathi et al. (2017), native breeds play an important role in backyard farming in Saudi Arabia, but they show low productivity, in particular low body weight (around $1000 \mathrm{~g}$ ) and low egg weight (around $40 \mathrm{~g}$ ). Selected native breeds of hens raised in Asia were characterised by Padhi (2016), who suggested that the low body weight and egg production of the native breeds can be improved through the use of proper breeding practices (with regard to environment and feeding) and by crossing them to achieve heterosis effect.

Anang et al. (2000) and Hocking et al. (2003) indicated that early maturing hens have genetically determined higher egg production, as evidenced by the generally negative correlations between age of sexual maturity and number of eggs; in our study, this relationship was only found in strains K-22 and A-33. Large differences were observed between the analysed strains in the age of sexual maturity, which was examined at $50 \%$ egg production. In the longer term, more attention should be given to the oldest hens of the native Z-11 breed, which were the last to mature and produced the smallest number of eggs, as also pointed out by Cywa-Benko (2002) and Krawczyk and Calik (2010). In the other populations, lack of selection had no adverse effect on the level of egg production, and the observed increase in the value of this trait over the course of years, must be ascribed to the considerable improvement in the environmental conditions, notably better quality of the feed. This is also indicated by the low heritability coefficients of this trait, which according to literature are in the $\mathrm{h}^{2}=0.1-0.3$ range (Szwaczkowski, 2003; Calik, 2008).

Over the 10 generations, egg fertility in all the analysed strains was high, with good hatchability from set and fertile eggs, which shows that these parameters im- 
proved compared to those reported by Cywa-Benko (2002). The obtained results are indicative of good health condition of the birds, appropriate hatching technique and environmental conditions, because, as reported by Szwaczkowski (2003), hatchability parameters are characterised by low heritability coefficients $\left(h^{2}<0.2\right)$. The fact that reproductive traits in the native breeds Polbar, Greenleg Partridge, Sussex and Rhode Island Red are stable, is also suggested by Gryzińska et al. (2015). Borzemska and Kosowska (1997) reported that hatching losses of 7.5 to $20 \%$, depending on species, breed and type of use, are considered physiological. Niedziółka (1997) observed that around $20 \%$ of artificial hatching failures were caused by poor storage of eggs, $20 \%$ died as a result of inappropriate incubator environment, and another $20 \%$ losses were due to improper turning of eggs during incubations. The author also indicated that around $40 \%$ of the other reasons for decreased hatchability are genetic factors, reproductive capacity of the birds, the effect of feeding, improper setting of eggs in the incubator, and various infections.

\section{Conclusion}

The analysis of the performance results of the eight strains of hens and their trends indicate that the methods of conservation breeding adopted for these populations enable effective implementation of the conservation programme. The strains were found to differ in all the performance traits subjected to evaluation. Over the 10 generations, the strains examined showed high survival and hatchability parameters during both rearing and production periods. The random mating system proved effective in preventing the populations from an increase in inbreeding. However, a worrying downward trend in body weight was observed in some strains.

\section{References}

A b d e lqa der A., Wo 11 ny C.B.A., G a u ly M. (2007). Characterization of local chicken production systems and their potential under different levels of management practice in Jordan. Trop. Anim. Health Prod., 39: 155-164.

A 1 d e r s o n L. (2010). Breeds at risk. Criteria and classification. Report from a seminar held in London. 16-17.02.2010, Convenor, 1: 1-14.

A nang A., M i el enz N., S c hüler L. (2000). Genetic and phenotypic parameters for monthly egg production in White Leghorn hens. J. Anim. Breed. Genet., 117: 407-415.

B o i c hard D., M a i g n el L., Verrier E. (1997). The value of using probabilities of gene origin to measure genetic variability in a population. Genet. Sel. Evol., 29: 5-23.

B orzem s k a W.B., K o s ow sk a G. (1997). Major problems of pathology in poultry hatch (in Polish). Zesz. Nauk. Prz. Hod., 3: 25-31.

B rodacki A., Zi ęba G., Cywa-B enko K. (2001). Genetic distance between selected breeds and lines of laying hens. Electron. J. Pol. Agric. Univ. - Anim. Husb., 4: 1-4.

Brodacki A., Tarkowski J., F lis J. (2003). Genetic distances in hens estimated with protein genes frequencies and procedures of DNA analysis. Electron. J. Pol. Agric. Univ. - Anim. Husb., 6: 56-61.

Caballe ro A., Toro M.A. (2000). Interrelations between effective population size and other pedigree tools for the management of conserved populations. Genet. Res., 75: 331-343.

C a 1 i k J. (2002). The relationships between body weight of hen and egg weight (in Polish). Rocz. Nauk. Zoot. Supl., 16: 95-102. 
Calik J. (2008). Analysis of some genetic and productive parameters and egg quality of hens from RIW (A-33) and RIR (K-22) conservation lines. Ann. Anim. Sci., 8: 113-119.

$\mathrm{Ca}$ lik J. (2009). Trends for productive and genetic parameters in three lines of laying hens over eight generations (in Polish). Rocz. Nauk. Zoot., 36: 31-43.

Ca lik J., K r a w c z y k J., S z e f e r M. (2012). Population status of laying hens enrolled in the animal genetic resources conservation programme in Poland (in Polish). Wiad. Zoot., 4: 31-39.

Cervantes I., Goyache F., Molina A., Valera M., Gutierrez J.P. (2011). Estimation of effective population size from the rate of coancestry in pedigreed populations. J. Anim. Breed. Genet., 128: 56-63.

Cywa-Benko K. (2002). Genetic and phenotypic characteristic of native chicken breeds encompassed in biodiversity conservation program (in Polish). Rocz. Nauk. Zoot., Rozpr. Hab., 15: 1-112.

Dobrzański J., Calik J., Krawczyk J., S zwaczkowski T. (2019). Conservation of goose genetic resources in Poland - past and present status. World's Poultry Sci., 75: 387-400.

F a th i M.M., A l. - Ho m id a n I., A b o u - E m e r a O.K., A l - Mo s haw a h A. (2017). Characterisation of Saudi native chicken breeds: a case study of morphological and productive traits. World's Poultry Sci., 73: 916-927.

Gryzińska M., Batkowska J., A l-Shammari K., A mbrożkiewicz J., Jeżewska- Wi t k ow ska G. (2015). Hatchability of selected breeds of hens maintained as Polish conservation flocks. Elect. J. Pol. Agric. Univ. - Anim. Husb., 18: 1-8.

$\mathrm{H}$ a z a r y R., K a t a ri a M., N a th M. (2000). Response to selection for egg mass in Rhode Island Red flock. Proc. XXI World Poultry Congress. Montreal, Canada, 22-25.08.2000, 12: 3.

H o c k in g P.M., B a in M., Ch a n n in g C.E., F 1 e m ing R., W i 1 s on S. (2003). Genetic variation for egg production, egg quality and bone strength in selected and traditional breeds of laying fowl. Brit. Poultry Sci., 44: 365-373.

K raw c z y k J. (2006). Determination of egg production profitability based on the relationship between chicken's body weight and egg weight (in Polish). Rocz. Nauk. Zoot., 33: 255-262.

K r a w c z y k J. (2018). Some productive traits of the native breeds of Greenleg Partridge and Yellowleg Partridge hens (in Polish). Wiad. Zoot., 2: 68-72.

K raw c z y k J., C a lik J. (2010). Comparison of performance in five generations of laying hens from Polish conservation flocks (in Polish). Rocz. Nauk. Zoot., 37: 41-54.

Krawczyk J., Puchała M., O brzut J. (2012). Hatchability in laying hen flocks under the conservation programme (in Polish). Wiad. Zoot., 4: 41-46.

Marquez G.C., S i e ge l P.B., Lew is R.M. (2010). Genetic diversity and population structure in lines of chickens divergently selected for high and low 8-week body weight. Poultry Sci., 89: $2580-2588$.

Mtileni B.J., Muchadeyi F.C., Maiwashe A., Chimonyo M., D zama K. (2012). Conservation and utilisation of chicken genetic resources in Southern Africa. World's Poultry Sci., 68: $727-747$.

Niedziółk a J. (1997). Physiological and zoohygienic bases of incubating eggs of gallinaceous bird (in Polish). Zesz. Nauk. Prz. Hod., 31: 15-23.

Özdemir D., Özdemir E.R., Marchi M.D., C as s andro M. (2013). Conservation of local Turkish and Italian chicken breeds: a case study. It. J. Anim. Sci., 12: 313-319.

$\mathrm{Padh}$ i M.K. (2016). Importance of indigenous breeds of chicken for rural economy and their improvements for higher production performance. Hindawi Pub. Corp. Sci., 1: 1-9.

Pham M.H., Tran X.H., B erthouly-Salazar C., Tixier-Boichard M., Chen C.F., L e e Y.P. (2016). Monitoring of genetic diversity in Taiwan conserved chickens assessed by pedigree and molecular data. Livest. Sci., 184: 85-91.

Polak G., Krupiński J., Martyniuk E., Calik J., Kawęcka A., Krawczyk J., Majewska A., Sikora J., Sosin-Bzducha E., Szyndler-Nędza M., Tomczyk-Wro$\mathrm{n}$ a I. (2021). Assessment of risk status of Polish local breeds under conservation programmes. Ann. Anim. Sci., 21: 125-140.

S e m i k E., K r a w c z y k J. (2011). The state of poultry genetic resources and genetic diversity of hen populations. Ann. Anim. Sci., 11: 181-191.

S ing h B., S ing h H., S ing h C.V. (2000). Genetic parameters of growth, egg production and egg quality traits in White Leghorn. J. Poultry Sci., 35: 13-16. 
Spalona A., Ranving H., Cywa-Benko K., Z anon A., S abbi oni A., S zalay I., B en kova J., B a umgartner J., S zw a c zkowski T. (2007). Population size in conservation of local chicken breeds in chosen European countries. Arch. Geflugelkd., 71: 49-55.

S z w a c z k ow s k i T. (2003). Use of mixed model methodology in poultry breeding: estimation of genetic parameters. In: Poultry genetics breeding and biotechnology. CABI Publishing, pp. 165-203.

Van M a r l e-Kö ster E., H e f e r C.A., N e l L.H., G ro e n e n M.A.M. (2008). Genetic diversity and population structure of locally adapted South African chicken lines: implications for conservation. South Afr. J. Anim. Sci., 38: 271-281.

Vostrý L., Vostrá-Vydrová H., Moravčíková N., Hofman ová B., Ry ch tářová J., Machová K., Brzáková M., Kasarda R. (2020). Monitoring of genetic diversity in autochthonous Czech poultry breeds assessed by genealogical data. Czech J. Anim. Sci., 65: 224-231.

Wężyk S., Cywa-Benko K., Siwek M., B ednarczyk M., Calik J. (2000). Studies on genetic differences in genetic reserve breeds of hens (in Polish). Rocz. Nauk. Zoot., 27: 115-127.

W o e ld e r s H., Z u i d b e r g C.A., H i e m st r a S.J. (2006). Animal genetic resources conservation in the Netherlands and Europe. Poultry perspective. Poultry Sci., 85: 216-222.

World Watch List for Domestic Animal Diversity (2000). FAO/UNEP, Roma, 3rd ed.

Wrigh t S. (1931). Evaluation in Mendelian populations. Genetics, 14: 97-159.

Received: 25 XI 2020

Accepted: 29 VII 2021 